\title{
Teaching in Times of COVID-19: The Evaluation of Distance Teaching in Elementary and Secondary Schools in Germany
}

\author{
Rebecca Schneider*, Karoline A. Sachse, Stefan Schipolowski and Florian Enke \\ Institute for Educational Quality Improvement (IQB), Berlin, Germany
}

To depict the situation during the school closures in spring 2020 that were implemented to contain the spread of COVID-19, we conducted a self-constructed online survey on distance teaching among teachers regarding their teaching practices in this new situation, the challenges they experienced, and the prerequisites for successful distance teaching.

OPEN ACCESS

Edited by:

Kathrin Lockl,

Leibniz Institute for Educational

Trajectories (LG), Germany

Reviewed by:

Lianjiang Jiang,

The Education University of Hong

Kong, China

Johanna Pöysä-Tarhonen, University of Jyväskylä, Finland

John Mark R. Asio,

Gordon College, Philippines

*Correspondence:

Rebecca Schneider rebecca.schneider@iqb.

hu-berlin.de

Specialty section: This article was submitted to Educational Psychology, a section of the journal

Frontiers in Education

Received: 29 April 2021 Accepted: 15 July 2021 Published: 03 August 2021

Citation:

Schneider $R$, Sachse $K A$, Schipolowski S and Enke F (2021) Teaching in Times of COVID-19: The Evaluation of Distance Teaching in Elementary and Secondary Schools

in Germany.

Front. Educ. 6:702406.

doi: 10.3389/feduc.2021.702406
The sample consisted of voluntarily participating German elementary $(n=857)$ and secondary school teachers $(n=1,590)$ from a sample of randomly drawn schools in four federal states in Germany. We describe the main survey findings and examine the importance of different distance teaching aspects for teacher reports of students attaining their learning objectives and students' learning progress during distance teaching. Our results particularly highlight the necessity for students and teachers to remain in contact in all the surveyed school types. In elementary school, regular contact between teachers and parents is similarly important. The key challenges highlighted inadequate digitalization, the participation of all students, and students' motivation. Correspondingly, adequate technical equipment for schools, teachers, and students, together with teachers' and students' competence to use technical devices and digital media as well as students' motivation to participate in distance learning were found to be necessary prerequisites for successful distance teaching. We conclude that efforts should be devoted to enabling teachers and students to better communicate using digital devices, for example, expanding the digital infrastructure in combination with training teachers and students in the use of technical devices and digital media.

Keywords: COVID-19, distance teaching, distance learning, home schooling, elementary school, secondary school

\section{INTRODUCTION}

Containing the spread of SARS-CoV-2 was one of the main aims worldwide in 2020 and is still an issue in 2021. Until vaccines are widely available to slow its spread, social distancing strategies are the main requirement for preventing overwhelmed health systems. Therefore, a wide variety of SARS$\mathrm{CoV}-2$-control policies, for example, restrictions on gatherings, workplace closures, national and international travel controls, testing, and contact tracing, were implemented. Since educational institutions host large numbers of students in enclosed spaces and could therefore potentially produce infection clusters, one additional main policy component was the closing of all educational institutions. More than 1.2 billion students had to deal with the closure of elementary schools, secondary schools, or higher education institutions (United Nations Sustainable Development 
Group, 2020). In total, 80 percent of children and young people worldwide were forced into being educated at home (Van Lancker and Parolin, 2020), millions of teachers suddenly faced the challenge of having to reorganize their lessons, and both teachers and students had to adjust to distance teaching ${ }^{1}$. In the sense of responsible science and to add empirical evidence to the research scope on distance teaching during the pandemic (see Helm et al., 2021, for a systematic overview of the state of quantitative research on teaching and learning characteristics during school closures due to the coronavirus), our aim was to describe the impact of the necessary school closures on education in Germany from the teachers' perspective. Furthermore, we examined the importance of different teaching practices on students attaining their learning objectives and students' learning progress during distance teaching. Our research findings, together with results from surveys on, for example, school administrators, students, and/or their parents, might be especially beneficial for developing pedagogical plans to better cope with comparable situations in the future.

\section{Pandemic Policy on Education in Germany}

The educational system in Germany is decentralized, with the authorities in the federal states being responsible for education quality. In order to contain the spread of SARS-CoV-2 in Germany, in the year 2020 all federal state governments closed educational institutions in mid-March (for a detailed chronology, see Fickermann and Edelstein, 2020) affecting around 9.1 million first to thirteenth graders, 2.6 million students in vocational training schools, and their approximately 830,000 teachers (Statistisches Bundesamt, 2020). The Ministries of Education or senate administrations of the German federal states issued an order for students to continue learning and to receive support while doing so. Therefore, distance teaching was implemented as an alternative to classroom teaching to allow for flexible learning arrangements depending on local infection rates (i.e., full distance teaching in the case of school closures or a combination of learning at school and at home) and flexible learning in terms of time (i.e., independent of educational institution cycles). Legally, distance teaching is defined as the transfer of knowledge and skills where teachers and students are spatially separated from one another and where teachers still monitor the learning success of students (Gesetz zum Schutz der Teilnehmer am Fernunterricht, 2020, \$1). In contrast to home schooling (which is prohibited under German law), work assignments are determined by designated teachers in accordance with school curricula, rather than by the parents (Tenorth, 2014). Depending on different governmental decisions in the German federal states, schools either fully opened in May 2020, re-opened only for graduating classes, or implemented a combination of learning at school and at home.

\footnotetext{
${ }^{1}$ In this paper we use the term "distance teaching." This should be considered equivalent to "distance learning," "distance education," "remote teaching," and "remote learning."
}

\section{Impact of School Closures on Teaching in Elementary and Secondary Schools}

Schools are considered institutions of learning and living. Students are expected to acquire specific learning content and competencies and take part in the social life of a school. Lessons as interactive spaces in which subject-specific and more general content can be taught and explored are at the core of schooling. During the SARS-CoV-2 pandemic, the goal of politics was to continue lessons and thus fulfill the school curricula. Teachers (and students) had to switch from classroom learning to distance learning within a few days, facing many challenges concerning technical equipment, pedagogical changes, governmental guidelines, and students' individual needs. However, no specific instructions in terms of teaching structure were provided, for example, which school subjects should be taught, to what extent teachers should provide learning opportunities, and which forms of support students and their parents should receive. As a consequence, the success of distance teaching mainly depended on how well teachers and students were equipped, prepared, and engaged in distance teaching.

Since then, many scientists have engaged themselves in research on distance teaching in Germany (for an overview see, e.g., Fickermann and Edelstein, 2020) as well as in other countries around the world (e.g., Assunção Flores and Gago, 2020; Ewing and Cooper, 2021; Khlaif et al., 2021). In this study, our aim is to contribute to the empirical evidence on the impact of school closures on education in Germany from the teachers' perspective for both elementary and secondary school education. In this context, we focused on aspects that can be associated with good teaching and the successful development of students' knowledge and skills to answer the following four questions: 1) Did teachers stay in contact with most of their students? 2) Which aspects did teachers focus on during lessons? 3) How did teachers organize their classes against the background of inadequate digitalization? 4) How did teachers factor in achievement differences between students? The significance of each of these questions is outlined in more detail below.

\section{Contact Between Teachers and Students}

One fundamental prerequisite for education during school closures is ensuring regular contact between teachers and their students (if necessary, mediated by students' parents) for providing learning opportunities, distributing learning material and work assignments, giving feedback, and providing a platform for exchanging experiences, emotions, or even fears relating to distance learning. Only when students take advantage of this offer to learn, can distance teaching lead to learning progress. Here, the percentage of students that teachers had contact with might indicate how many students were involved in lessons or became increasingly isolated-providing teachers actually offered interaction opportunities. Because elementary school students might be more dependent on parental support during distance teaching, the percentage of teachers having frequent contact with their students might be lower in elementary compared to secondary schools. Conversely, it can be assumed 
that more elementary school teachers communicated directly with their students' parents.

\section{Aspects Teachers Focused on During Lessons}

In school, teachers are required to provide learning opportunities for students to engage with learning content and develop corresponding competencies. As shown in many studies, opportunities to learn are an important determinant of differences in scholastic achievement (Scheerens, 2017). With regard to distance teaching, Klieme (2020) recommended offering opportunities for learning along the curriculum with tasks varying in difficulty. In terms of quality of instruction, demanding content should not be excluded to avoid specific content being arbitrarily neglected in an uncontrolled manner. In contrast, repeating already learned content and postponing the introduction of new content might be problematic because the rehearsal of previously learned content could be associated with lower aspiration levels and underload, which is related to boredom (e.g., Acee et al., 2010), and, consequently, lower scholastic achievement (Hattie, 2020). Furthermore, Klieme (2020) encouraged teachers to assess the learning progress of their students via curriculum-based diagnostic tests to identify content areas that need further instruction as well as identify students with learning deficits. For this, diagnostic tests would allow for rapid, smooth, and more adaptive teaching. Gaps in knowledge and understanding would otherwise only be discovered coincidentally during lessons, with subsequent time-consuming explanations that interrupt the planned structure of lessons and exclude some students. Overall, teaching new content together with periodic diagnostic tests are desirable aspects that teachers should implement during distance teaching.

\section{Organization of Classes Against the Background of Inadequate Digitalization}

With schools being closed and distance teaching implemented, "online learning opportunities have been elevated from a bonus extracurricular facility to a critical lifeline for education" (Organisation for Economic Co-operation and Development [OECD], 2020, p. 1). National and international studies indicate that German schools and teachers were not well prepared for distance teaching using technical devices and digital media. Serious deficits were reported for equipment in schools with Germany being well below the OECD average with regard to the availability of IT equipment, Wi-Fi, learning management systems and internet-based applications for collaborative working, and the supply of teachers with individual technical devices. Consequently, only around 60 percent of secondary school teachers in Germany reported using digital media in school for school-related purposes at least once a week, with around 23 percent using digital media daily (ICILS study; Eickelmann et al., 2019). In elementary school, digital media were used to an even more limited extent than secondary school (Schmid et al., 2017) and the use of digital media in this case depended largely on the commitment (e.g., personal interests, competencies) of teachers and principals (Thom et al., 2017). These findings indicate that a stronger use of digital media for learning during school closures might be a new experience for many German students.

Against the background of the unsatisfactory state of digitalization in German education, it is of particular interest to examine how teachers organized their lessons during school closures. It can be assumed that teachers mainly used presentation modes and distribution methods having low technical requirements, for example, relying on exercises in text books or sending working sheets/feedback to students via e-mail-especially in elementary school where students were even less familiar with technical devices and digital media compared to secondary school students. Besides asking "how," it is also important to examine "how often" teachers used the different presentation modes, sent out work assignments and teaching materials, or gave feedback to their students. As research indicates, giving short work assignments on a regular basis is more effective than giving extensive assignments (Schnyder et al., 2006) and allows for the adaptation of subsequent learning material and work assignments. Furthermore, prompt and regular feedback on these assignments is essential for successful learning (McLaughlin and Yan, 2017) and appears to increase motivation in students (Trautwein et al., 2001; Khlaif et al., 2021).

\section{Handling Achievement Differences Between Students}

Because students vary, for example, in their social and cultural backgrounds, learning pace, or scholastic achievements, teachers should give differentiated instructions assuming that "students learn best when their teachers effectively address variance in students' readiness levels, interests, and learning profile preferences" (Tomlinson, 2005, p. 263). During the pandemic, concerns about students' learning progress were widespread among educational management, policy makers, and educational scientists. More specifically, higher learning lags were assumed for students from socially deprived families, students with immigration backgrounds, and students with special needs (e.g., Di Pietro et al., 2020; Hurrelmann and Dohmen, 2020; Leopoldina, 2020; Van Ackeren et al., 2020). For example, students from socially deprived families typically have less available socio-cultural capital and therefore fewer resources that might help them learn at home (e.g., technical devices; Andrew et al., 2020) than students from families with higher incomes. Students with immigration backgrounds (associated with a lower socioeconomic status) might additionally have problems understanding the language of instruction (Kempert et al., 2016) and necessary language tuition or additional teacher support might have been dropped. Furthermore, for students from both groups, it is likely that their parents struggle more to help their children learn at home and be an additional audience for feedback. It can be expected that teachers identified these groups of students as being disadvantaged by distance teaching.

To maximize individual learning success, instruction should be individually adjusted depending on the achievement level of the student. For example, Thakur (2014) recommends differentiation by individually adjusting learning content (tasks 
should be appropriate to students' individual experience or knowledge level and students should use different resources in accordance with their learning style), processes (varying the presentation mode of instructions), and products (showing gained knowledge through individualized outcomes/products). In conjunction with perceived stress (e.g., Huber et al., 2020; Klapproth et al., 2020) and/or less knowledge when dealing with technical devices and digital media, teachers might have less time and/or lack the necessary competencies to factor in achievement differences between students during distance teaching. Additionally, it might be more difficult to assess learning during distance teaching (less interactions with students, less diagnostic tests) and therefore to adapt learning material and work assignments. However, since teachers typically know their students and their strengths and weaknesses well, it can be assumed that many teachers used differentiated instructions independent of the examined school type.

\section{Challenges of Distance Teaching and Prerequisites for Successful Distance Teaching}

In addition to exploring the teaching structure, teacher-reported challenges and prerequisites for successful distance teaching might provide further indications of aspects that should be targeted first due to their particular importance to distance teaching. Consistent with the unsatisfactory state of digitalization in German education described in the ICILS study (Eickelmann et al., 2019), empirical evidence regarding competencies in using technical devices and digital media appears to reinforce concerns about the lack of preparation of teachers and students for distance teaching: According to principals, only half their teachers had the necessary technical and pedagogical skills to integrate technical devices and digital media into instruction. Simultaneously, around only 40 percent of principals reported that effective professional resources for teachers to learn how to use digital devices were available to their staff (Organisation for Economic Co-operation and Development, 2020). On the other hand, nearly all German secondary school teachers reported confidence in finding useful teaching material on the Internet and 80 percent were also confident in preparing lessons for students using digital media. However, only one third of the teachers used learning management systems. In terms of students, around 91 percent of 15-year-old students reported having a computer for working at home and nearly all students (99 percent) reported having access to the Internet (Behrends et al., 2018; Organisation for Economic Co-operation and Development, 2020). In an international comparison of these statistics, Germany is in the leading group of OECD member countries. Nevertheless, it is conceivable that these requirements are inadequate because families with several school-aged children and/or parents working from home could rapidly reach their capacity limit of device availability. Relating to this, only 43 percent of German 12year-olds and 52 percent of 14-year-olds report having a computer or tablet for their own use. For students in socially deprived families, the corresponding percentages are even lower
(Geis-Thöne, 2020). This defies the constitutional right of all students for equal access to high-quality education. However, computer- and information-related competencies of German eighth graders were above the international average in 2018 and Germany was ranked in the middle section for this field in an international comparison. Associated with this, around one third of eighth grade students only have rudimentary or basic computer- and information-related competencies and another quarter of the students are able to use digital media autonomously and critically. Based on these data, it is conceivable that teachers list mainly the same aspects focusing on inadequate digitalization as the researchers and politicians-particularly in elementary schools where teachers and students are less familiar with technical devices and digital media. Thus, prerequisites for successful distance teaching should consequently focus on aspects of digitalization.

\section{Students' Attainment of Learning Objectives and Learning Progress}

Beyond describing the impact of school closures on education in Germany from the teachers' perspective, our aim was to examine the importance of different teaching practices for the students' attainment of learning objectives as well as their learning progress during distance teaching. The initial results of empirical studies indicate that students were less engaged in school-related activities in general and learning activities in particular during the first German school closures in spring 2020 (e.g., Grewenig et al., 2020; Wößmann et al., 2020), they were less motivated to learn, and had different and possibly fewer interactions with their teachers (e.g., Di Pietro et al., 2020). Correspondingly, school closures had detrimental effects on learning gains and social disparities during the first wave of the pandemic in Germany (Depping et al., 2021; Schult et al., 2021) and other countries (e.g., Maldonado and De Witte, 2020; Engzell et al., 2021). Which aspects should educational management, policy makers, and others involved in education focus on to ensure that as many students as possible achieve their targeted learning goals and therefore show learning gains? Contact with students and/or parents as well as access to technical devices for both teachers and students are undoubtably fundamental prerequisites for distance teaching. However, new devices might be of less value if teachers and/or students do not know how to use them adequately. In addition, research by Hattie (2020) on 1,400 meta-analyses indicates the substantial impact of, for example, feedback $(d=0.73)$ on students' academic achievement. The reported relationships and effect sizes can only be applied to traditional classroom teaching. For distance teaching, we do not know of any comparable ranking sequences. Yet these analyses can help highlight important aspects related to successful distance teaching and, therefore, enrich the professional discourse and political debate on future interventions.

\section{The Current Study}

In order to inform policy and practice as well as initiate further research on the impact of school closures on education in 
Germany, we conducted an online survey on distance teaching among nearly 2,500 teachers. Our aim is to present data describing teaching practices during the first wave of school closures in spring 2020 and summarize the teacher-reported challenges of distance teaching as well as prerequisites for successful distance teaching. Moreover, we examined the importance of different teaching practices for students' attainment of learning objectives and learning progress during distance teaching using data mining supervised machine learning, which is a state-of-the-art method in exploratory data analysis. To gain further insights into potentially differing teaching practices depending on students' age, analyses were conducted separately for elementary and secondary school students and subsequently compared. We then related our findings to corresponding results from other surveys in the discussion.

\section{MATERIALS AND METHODS}

\section{Sample and Procedure}

Responses were collected from an online survey conducted in June and July 2020 (i.e., at the end of the school year) from teachers in different states in Germany. The original sample comprised answers from elementary school teachers in 15 of the 16 German federal states and responses from secondary school teachers in four states. To ensure the comparability of the results between elementary and secondary schools, we only analyzed data from the four federal states where teachers from both levels of education had participated (for comprehensive descriptive results for elementary schools, see Schneider et al., 2020).

Depending on the state, either all public schools of the state were invited to participate in the survey or only a representative sample that was randomly drawn from a complete list of all schools in the respective state provided by school authorities. Headmasters of the invited schools were asked to distribute the hyperlink for the survey among all teachers currently working as form teachers at the school. The open source software LimeSurvey $^{2}$ was used to administer the survey. At the beginning of the questionnaire, form teachers were asked to respond to the questions on distance learning with regard to their class; other (i.e., non-form) teachers were also accepted as participants and required to choose a class for which they would answer the questions. All teachers were instructed to consider the last 4 weeks of mere distance learning.

Participation was voluntary and anonymous. Complete questionnaires were submitted by $n=857$ elementary school teachers (gender: 88 percent female, 9 percent male, 3 percent diverse or unspecified; age: $M(S D)=44.21$ (9.61) years) and $n=$ 1,590 secondary school teachers (gender: 66 percent female, 31 percent male, 2 percent diverse or unspecified; age: $M(S D)=45.01$ (10.13) years; school type: 42 percent academic track, 58 percent non-academic track) and these were included in the following analyses. Participation quotas

${ }^{2}$ https://www.limesurvey.org/ are not available as participants cannot be linked to schools based on the survey data; however, the gender and age distribution in our teacher sample are similar to the respective population statistics reported in large-scale educational monitoring studies (e.g., Rjosk et al., 2017).

\section{Instrument}

The survey consisted of 28 questions, including nine questions concerning the teachers' personal information (e.g., gender, age) and their students/school (e.g., grade level, school type) and 19 questions about distance teaching that were assigned to three general topics: 1) teaching practices, 2) teachers' evaluation of different distance teaching aspects and their improvement, and 3) students' learning progress. The 13 distance teaching-related questions that were used for the analyses in the current paper (Table 1) can be categorized as follows in six (sub-)topics:

1a) Teachers' contact with students and parents,

1b) teachers' focus on different aspects during lessons,

1c) the organization of lessons against the background of inadequate digitalization,

1d) how to factor in achievement differences between students as well as the potential disadvantages for certain students due to distance learning,

2) the evaluation of different aspects of distance learning as well as prerequisites for successful distance teaching, and

3 ) the teacher-estimated learning progress of students.

Due to the unique and novel situation of distance teaching during school closures, we did not use existing questionnaires, but devised the questions specifically for the current study to cover our research questions. Only few results from other studies on distance teaching during the pandemic in Germany were available at the time and were considered during questionnaire development (e.g., forsa, 2020a).

\section{Analyses}

Analyses were conducted separately for elementary and secondary school using SPSS and R. For questions with closed response formats, frequencies or percentages were reported. Where appropriate, multiple answers were allowed for these questions. To evaluate the open question with more extensive answers, a categorical system built on the main motives of each response was created: First, a subsample of 300 teachers who answered the question (multiple answers per teacher were possible) was randomly selected. Subsequently, each answer was summarized in accordance with the qualitative content analysis according to Mayring (2015), paraphrasing answers until evaluable and comprehensible main categories were available. Second, trained raters assigned the subsample answers to the main categories independent of each other. If the interrater reliability was unsatisfactory (Cohen's kappa $\kappa<$ 0.60; Landis and Koch, 1977), the definition of the respective category was revised, adjusted, reassigned, and rechecked. If the interrater reliability was at least satisfactory (final $\kappa$ was .83 ), the resulting category system was applied to the remaining answers. 
TABLE 1 | Questionnaire content summary.

Question $^{\mathrm{a}}$

\begin{tabular}{|c|c|c|}
\hline Response format & Topic $^{b}$ & $\begin{array}{c}\text { Figure/ } \\
\text { Table }\end{array}$ \\
\hline closed & $1 \mathrm{a}, 3$ & Figure 1 \\
\hline closed & $1 b$ & Figure 2 \\
\hline closed & $1 c, 3$ & Figure 3 \\
\hline closed & $1 c$ & - \\
\hline closed & $1 c, 3$ & Figure \\
\hline closed & $1 c, 3$ & Figure 5 \\
\hline closed & $1 d$ & - \\
\hline closed & $1 d, 3$ & Figure 6 \\
\hline closed & $2,3^{\mathrm{C}}$ & Figure 7 \\
\hline open & 2 & Table 2 \\
\hline closed & 3 & Figure 8 \\
\hline closed & 3 & - \\
\hline closed & 3 & - \\
\hline closed & 3 & - \\
\hline open & 3 & - \\
\hline closed & 3 & - \\
\hline closed & $1-3^{d}$ & - \\
\hline
\end{tabular}

How many students and parents, respectively, did you stay in touch with on a regular basis during school closures?

What aspects did you mainly focus on with your teaching material and work assignments during distance teaching in

comparison to regular classroom teaching?

How often did you use the different presentation modes to present learning content in German?

How often did you use the different presentation modes to present learning content in mathematics?

How often did you distribute work assignments and learning material to your students via different communication

channels?

How often did you give feedback to the students via different communication channels?

Which students do you consider to be especially disadvantaged by distance teaching?

How did you handle achievement differences between students during school closures?

How good did distance teaching work with regard to the following aspects?

Which preconditions are most important for successful distance teaching?

In your opinion, what percentage of students managed to obtain at least the same learning progress during distance

teaching that could have been expected during classroom teaching?

Which factors impeded the organization of distance teaching for you?

How was the contact between students and teachers organized during distance teaching?

Are you female, male, or diverse?

How old are you?

Which grade level does the class you are answering this questionnaire for belong to?

What type is the school you are currently working at?

Notes. ${ }^{a}$ Translated from German.

"Indicates which topic the respective question belongs to (see text, section "Instrument").

"This question's closed items "attainment of learning objectives" and "ensuring the equal participation of all students" were used for analyses concerning topic 3.

${ }^{d}$ Results are presented separately for school types (topics 1a to 2: elementary and secondary school; topic 3: elementary school, non-academic track, academic track).

In order to explore which variables were most important for the teacher-reported attainment of learning objectives and the prediction of learning progress by students perceived by teachers, we used random forests (Breiman, 2001), a wellestablished data mining supervised machine learning method (e.g., Strobl et al., 2009). Prior to this, we analyzed the correlational structure of the data. Because our data were ordinally scaled we grew random forests consisting of ordinal regression trees (Janitza et al., 2016) using the R package party (Hothorn et al., 2021). We ran separate analyses for two different dependent variables (teacher-reported achievement of overall learning objectives and teacher-reported learning progress in comparison to classroom learning) and three subsets of our data that were split according to school type (elementary school, academic track in secondary school, and non-academic track in secondary school) resulting in six random forests. In every subset for both dependent variables we added the same set of selfreported measures as predictors. Each of our random forests consisted of 5,000 ordinal regression trees; robustness checks showed that this was sufficient as further increasing the number of trees yielded the same results. We computed four different variable importance measures (VIM) for each variable in each subset. As recommended by Janitza et al. (2016), our final variable ranking relied on the ranked probability score (RPS) VIM, but in general the ranking of variables was very similar among all VIMs considered. For the construction of the trees, 63.2 percent of the data were sampled without replacement and used as a training set as suggested by Boulesteix et al. (2012). Furthermore, we set the number of input variables sampled as candidates at each node to five.

\section{RESULTS}

\section{Impact of School Closures on Teaching in German Elementary and Secondary Schools}

The statistics describing the implementation of distance teaching in elementary and secondary schools in Germany following the sequence of aspects outlined in the introduction are reported below.

Figure 1 shows the results for how successfully teachers stayed in contact with their students and parents during distance teaching (topic 1a). A large majority of teachers in both elementary and secondary school had regular contact with most or all of the students in their class. However, there was also a non-negligible proportion of teachers in both school types reporting only regular contact with half or even fewer of their students. Regular contact with parents was much more frequent for elementary schools than for parents of older students.

Another important aspect of distance teaching is how work assignments are designed and communicated (topic 1 b). Figure 2 shows how the content of learning materials used during distance teaching differed in comparison to assignments in regular classroom learning. The results are similar for elementary and secondary schools. Most notably, assignments in distance teaching focused much more often on repetition and practicing already learned content, whereas the introduction of new topics and content was often postponed. For both school types, many teachers reported having rarely or not at all assessed the learning progress of the students. 
A contact with students: elementary school

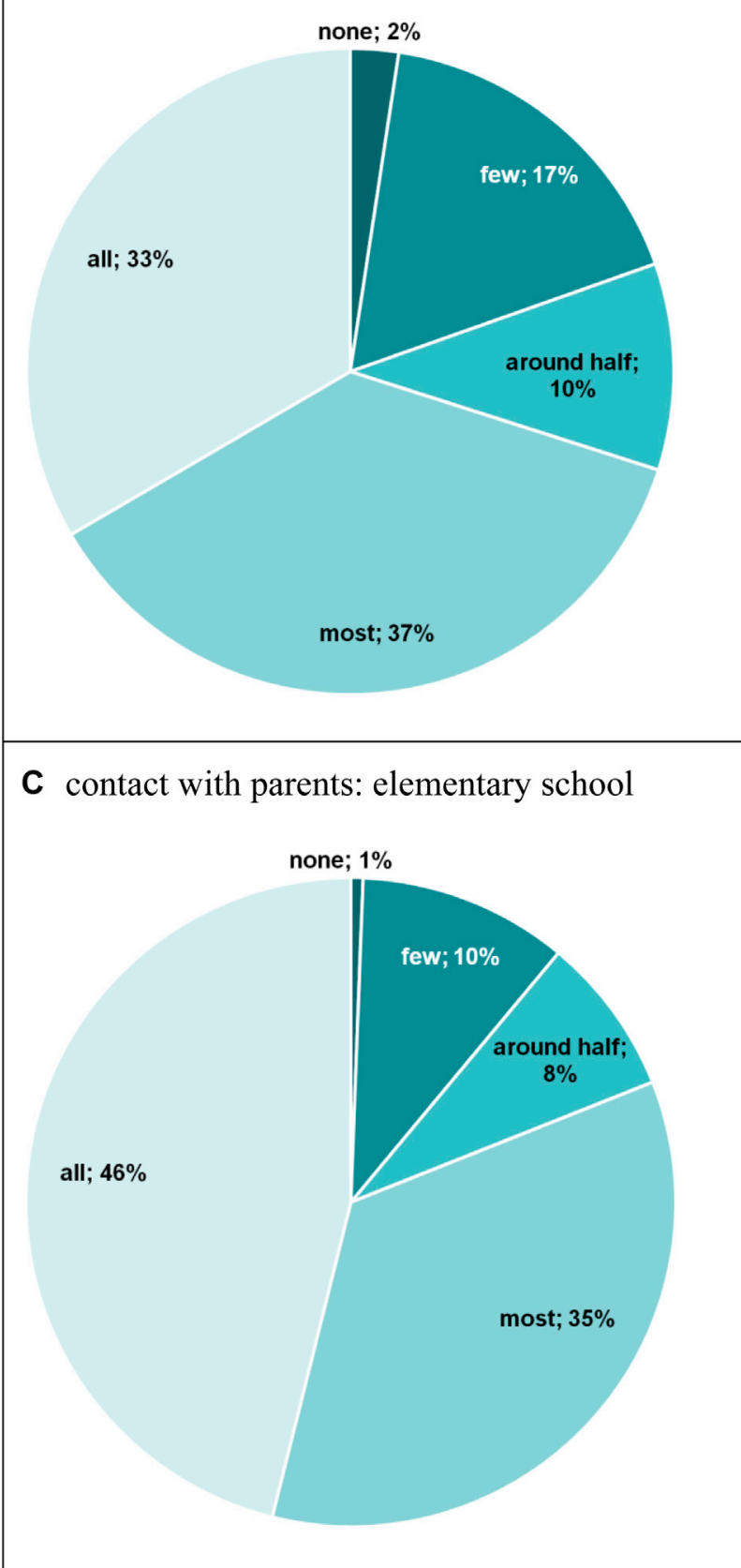

B contact with students: secondary school

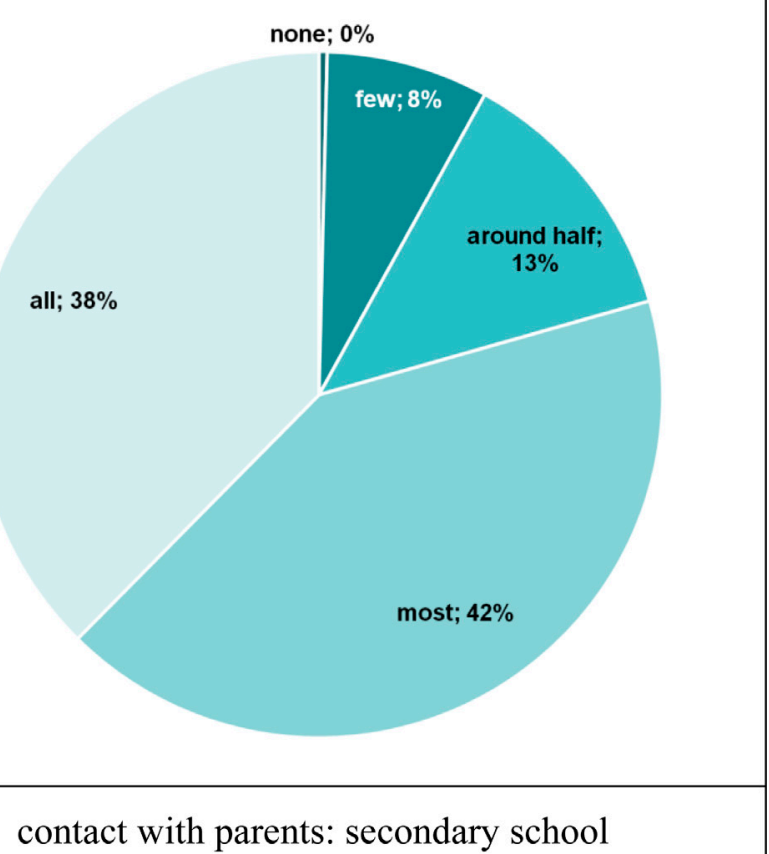

D contact with parents: secondary school

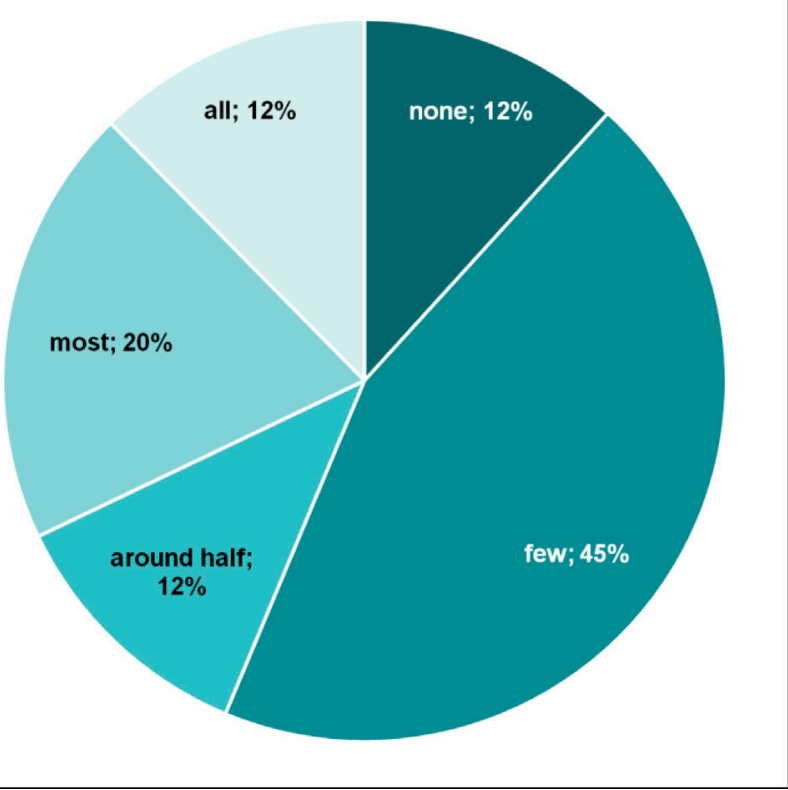

FIGURE 1 | Percentage of teachers giving the indicated responses to the question "How many students and parents, respectively, did you stay in touch with on a regular basis during school closures?" (A) contact with students: elementary school. (B) contact with students: secondary school. (C) contact with parents: elementary school. (D) contact with parents: secondary school.

Next, we examined teachers' organization of lessons against the background of inadequate digitalization (topic 1c). Figures 3 , 4 illustrate how teachers presented learning content to students and which communication channels they used to distribute learning materials and work assignments. In both cases, the percentages shown reflect the proportion of teachers in elementary and secondary schools, respectively, using a presentation mode or means of communication on a regular basis (i.e., at least once a week). The results show that teachers most often used presentation modes and ways to deliver assignments that had low-level technical requirements, such as assignments in textbooks or on worksheets sent via e-mail or kept 


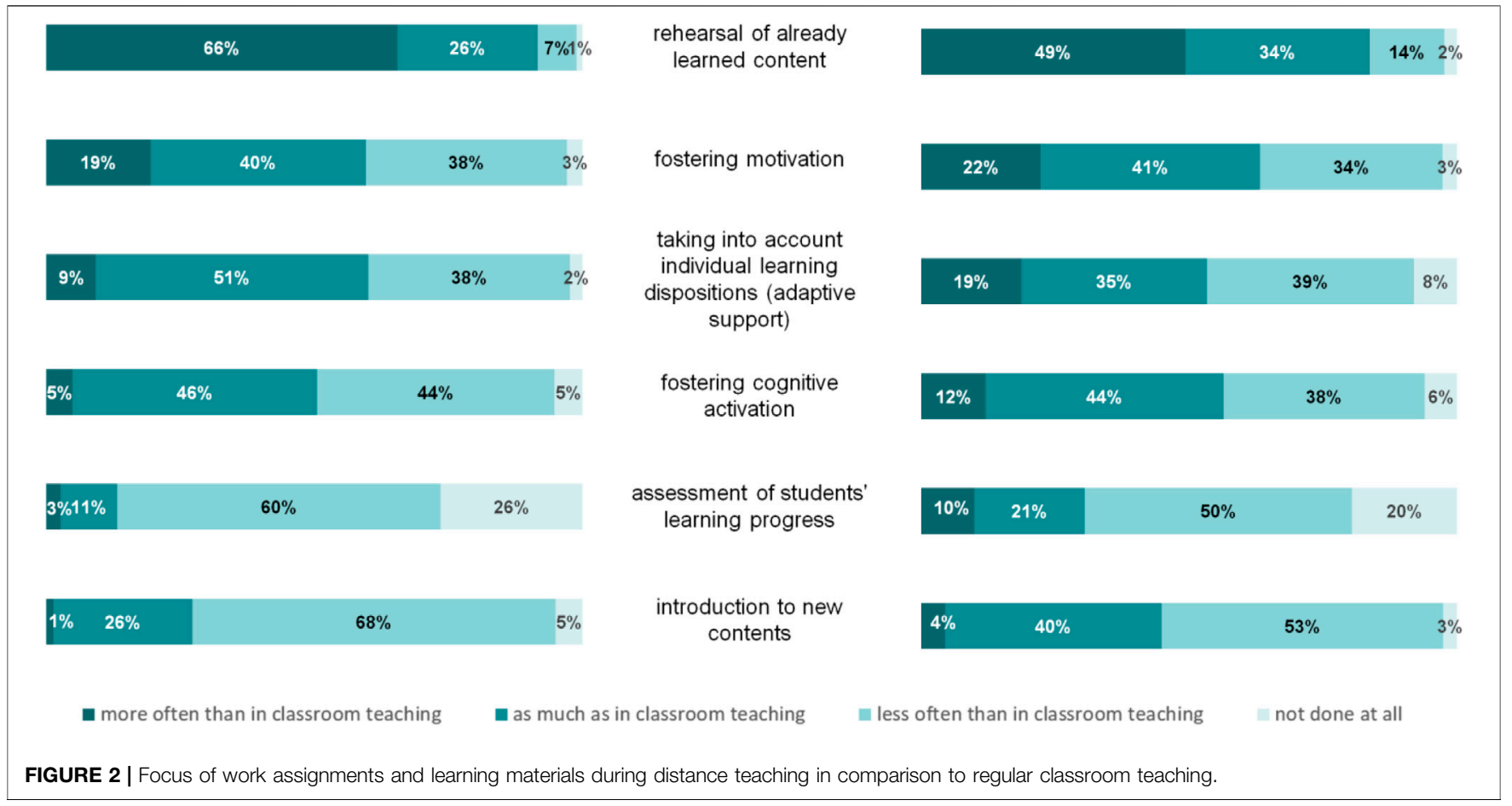

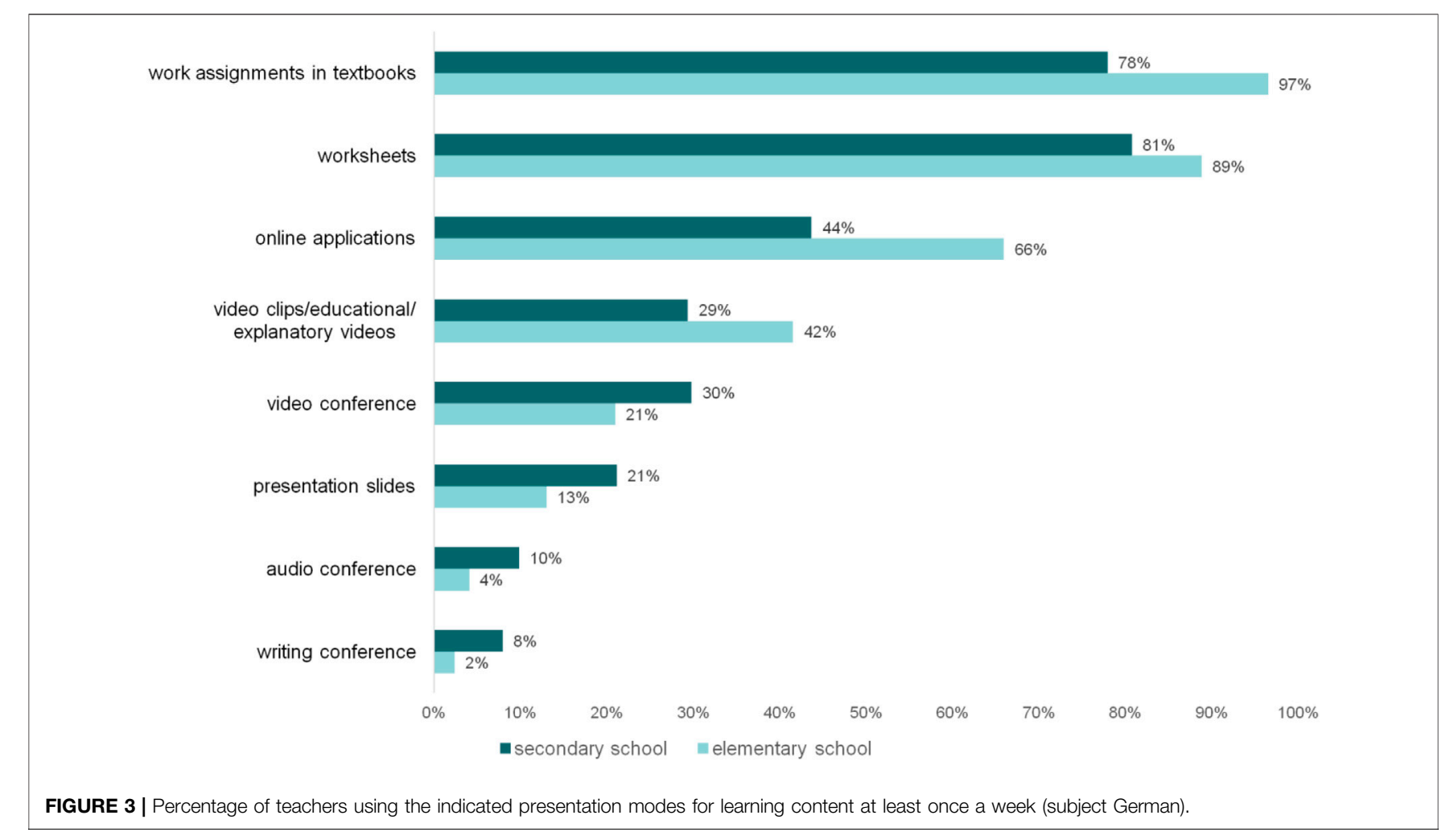

at school for pickup. However, many teachers also regularly used online platforms and apps for distributing assignments (especially in secondary school); about one quarter to 38 percent had video or audio conferences with their students. At secondary schools, the use of technically more advanced ways of communication, such as video or audio conferences, 


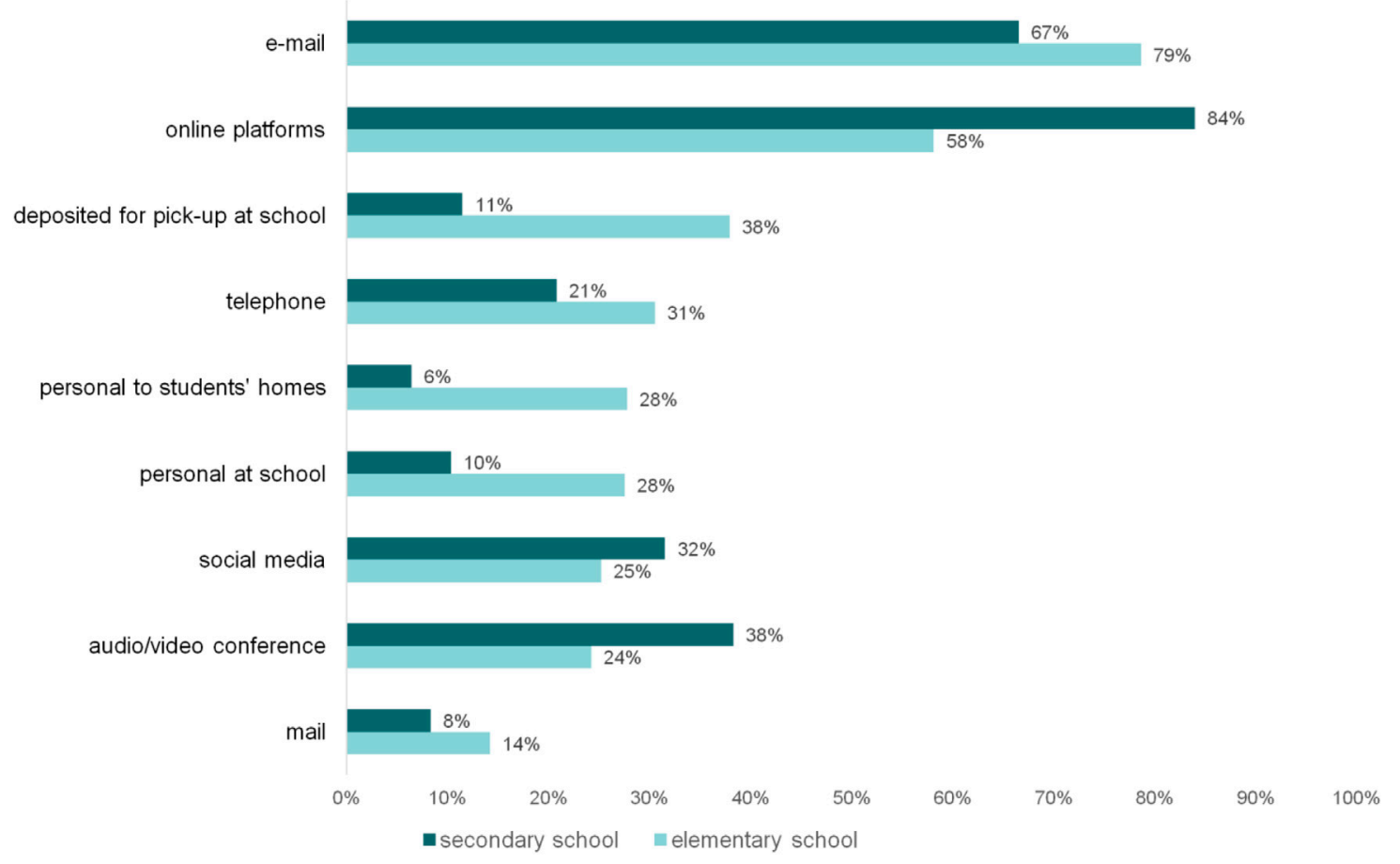

FIGURE 4 | Percentage of teachers using the indicated communication channels to distribute work assignments and learning material at least once a week.

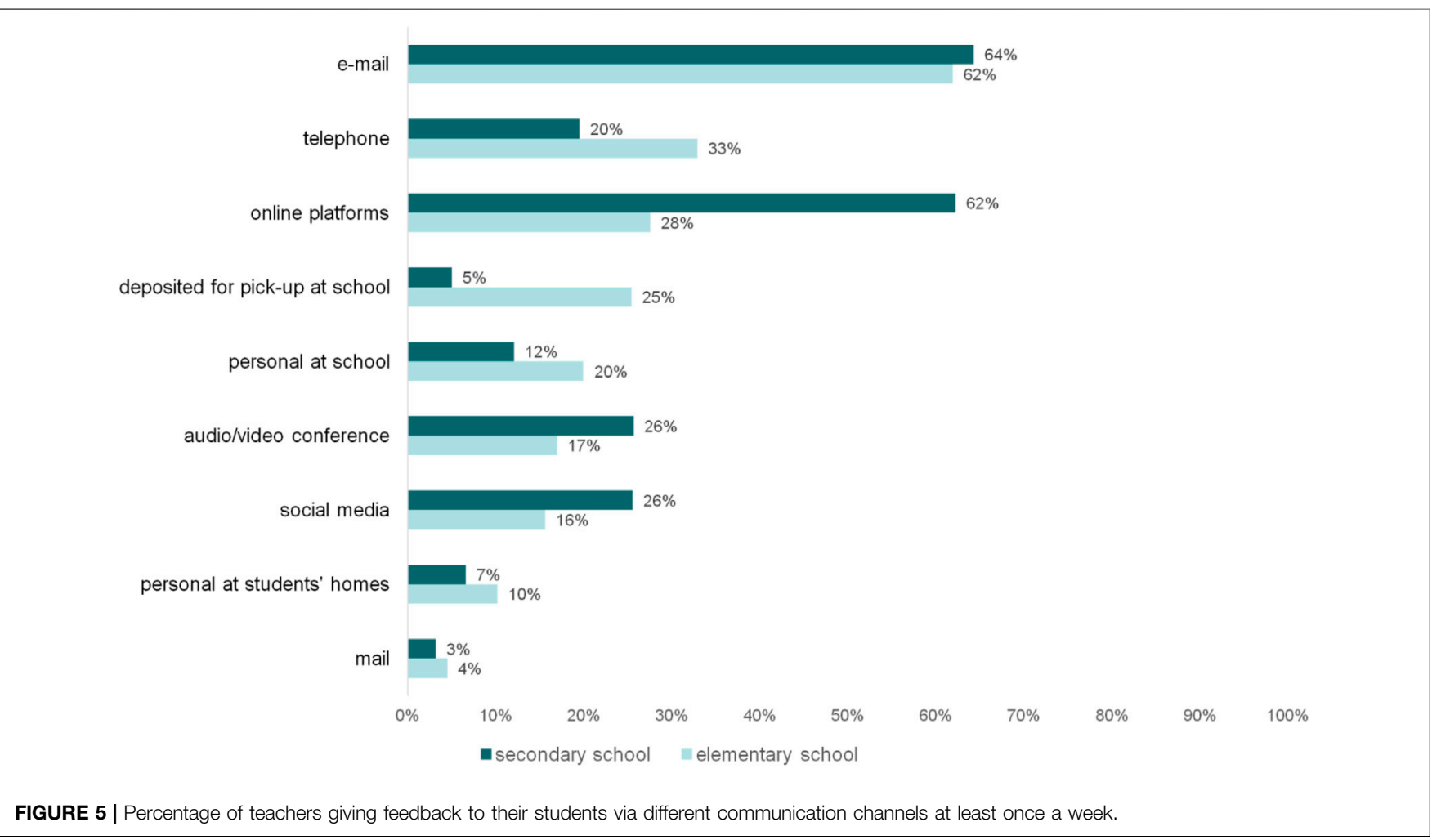




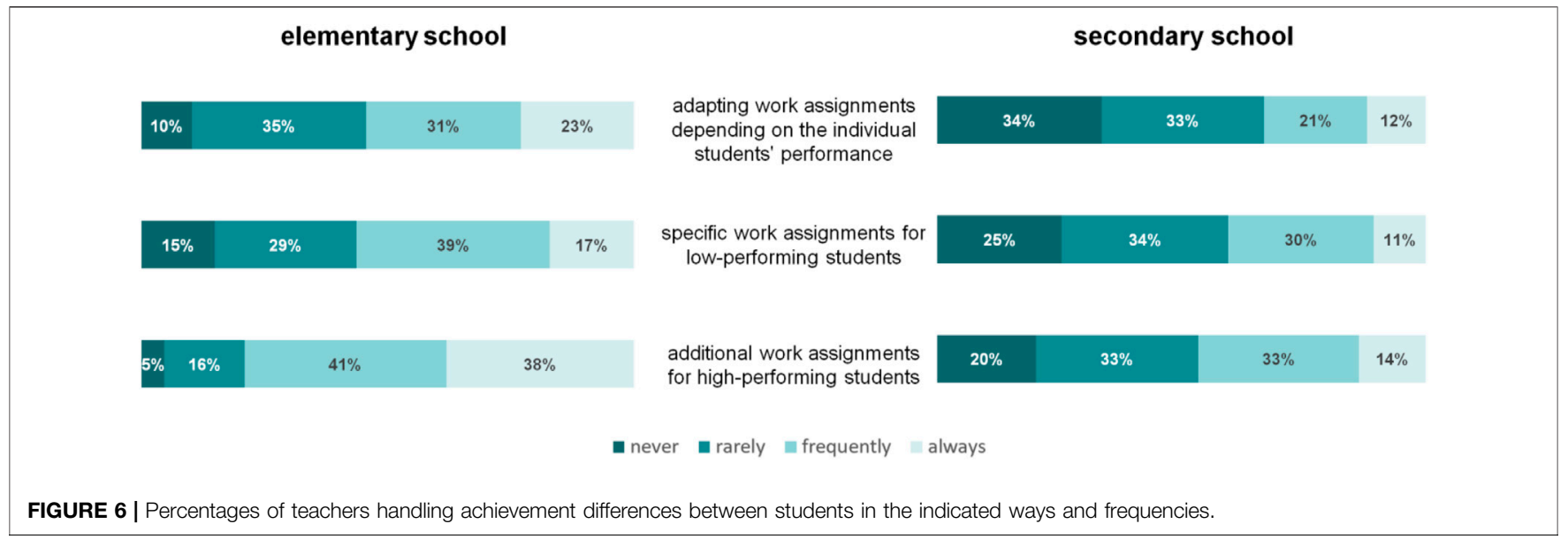

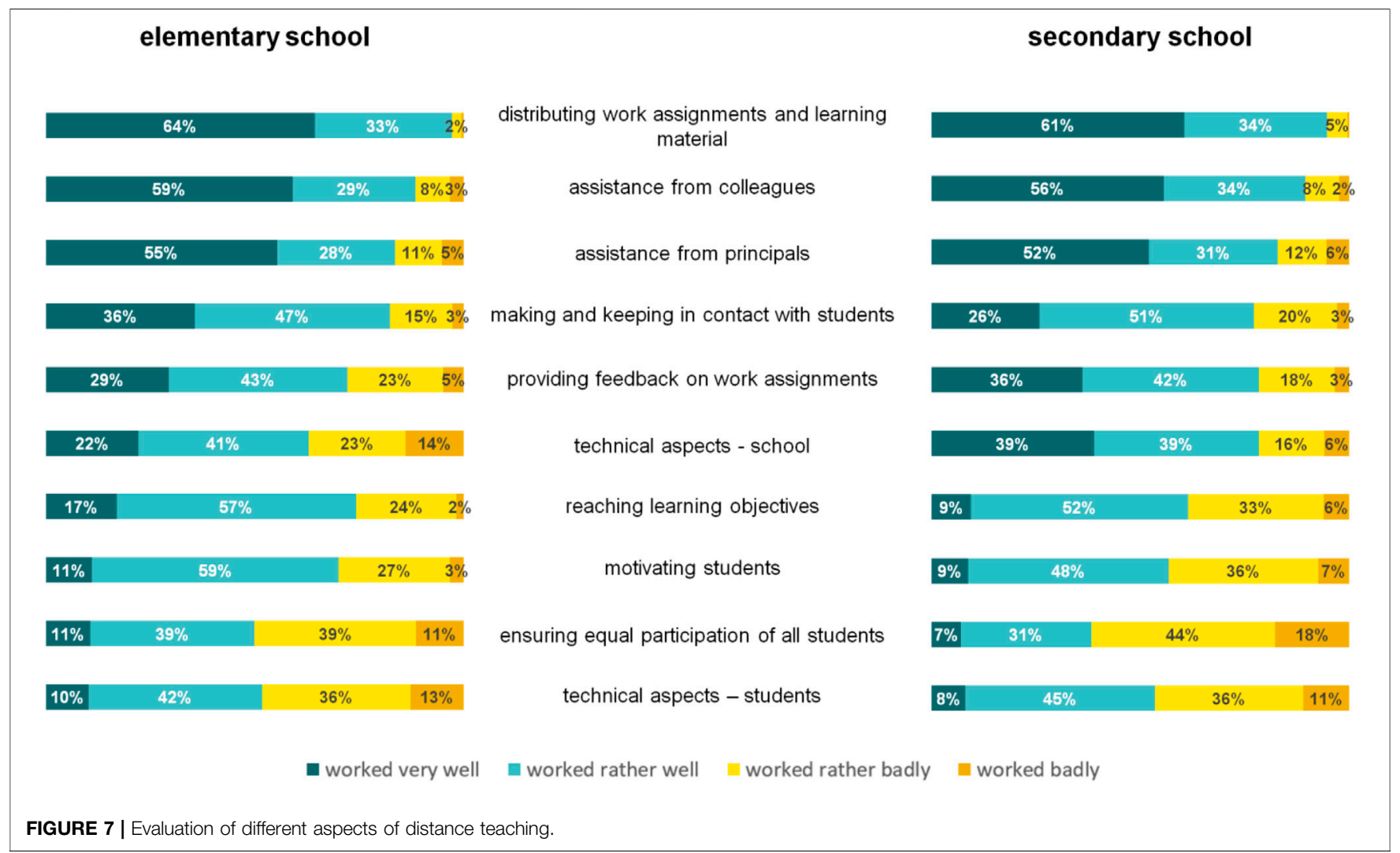

was slightly more frequent than in elementary schools. Results were very similar for mathematics (not shown) and German.

Another important aspect of distance teaching is how often and in which ways students receive feedback from teachers (e.g., concerning the correctness of completed learning assignments). At elementary schools, nearly all teachers (98 percent) gave students feedback at least once a week. Results were similar for teachers at secondary schools (97 percent). For both school types, e-mail was the most important means of communication for feedback (Figure 5). At elementary schools, teachers also often used the telephone or offered a pick-up at school. Feedback on a regular basis (i.e., at least once a week) via online platforms was provided by one third of elementary school teachers. However, the regular use of online platforms for feedback was much more frequent at secondary schools.

With regard to the handling of achievement differences between students (topic 1d), our survey showed that more than 85 percent of teachers at elementary and secondary schools considered students from families facing difficult social 
TABLE 2|Frequencies for the categorized responses with regard to the open question asking elementary school (ES) and secondary school (SS) teachers to name the most important preconditions for successful distance learning. The table is sorted in descending order according to ES.

\begin{tabular}{|c|c|c|c|c|}
\hline \multicolumn{2}{|c|}{ Frequencies in \% } & \multirow[t]{2}{*}{ Category } & \multirow[t]{2}{*}{ Description } & \multirow[t]{2}{*}{ Sample examples } \\
\hline ES & SS & & & \\
\hline 77 & 75 & technical equipment & availability of devices, e.g., tablets or laptops & $\begin{array}{l}\text { "all students must have access to appropriate devices," "teachers } \\
\text { must be provided with digital devices by their employer" }\end{array}$ \\
\hline 60 & 61 & IT infrastructure & IT infrastructure improvement & "working internet and wifi", "more IT staff" \\
\hline 30 & 24 & communication & $\begin{array}{l}\text { communication with parents, students and } \\
\text { between school staff }\end{array}$ & $\begin{array}{l}\text { "regular contact with students and parents," "regular feedback from } \\
\text { the teacher on work results" }\end{array}$ \\
\hline 29 & 34 & digital competence & $\begin{array}{l}\text { demand for further training in the area of media/ } \\
\text { digital literacy }\end{array}$ & $\begin{array}{l}\text { "training on video conferencing with large groups and working with } \\
\text { learning platforms" }\end{array}$ \\
\hline 26 & 17 & parental support & requests for cooperation of parents & $\begin{array}{l}\text { "parents need to better structure their children's daily routine," } \\
\text { "clarify that completing assignments is mandatory" }\end{array}$ \\
\hline 24 & 29 & $\begin{array}{l}\text { school/educational } \\
\text { software }\end{array}$ & specific software required for distance teaching & $\begin{array}{l}\text { "increased use of learning apps," "make better use of online offerings } \\
\text { from publishers/platforms," "easily accessible learning portals" }\end{array}$ \\
\hline 17 & 31 & general regulations & $\begin{array}{l}\text { comments on general regulations such as } \\
\text { compulsory education and data protection }\end{array}$ & $\begin{array}{l}\text { "specifications as to which external providers may be used and } \\
\text { whether or how achievement monitoring should be used" }\end{array}$ \\
\hline 7 & 17 & $\begin{array}{l}\text { student-related aspects } \\
\text { of teaching }\end{array}$ & $\begin{array}{l}\text { students' competencies for successful participation } \\
\text { in distance teaching }\end{array}$ & "foster student motivation and self-organized working" \\
\hline$<5$ & 18 & performance evaluation & evaluation/grading of tasks completed by students & $\begin{array}{l}\text { "mandatory participation in distance teaching with performance } \\
\text { evaluation is required" }\end{array}$ \\
\hline
\end{tabular}

Notes. The sample examples have been translated into English. Multiple responses per teacher were possible.

circumstances as well as students who rarely speak German at home to be especially disadvantaged by distance teaching. The question of how far teachers adapted their teaching for students with different educational needs during school closures was handled quite heterogeneously in both school types (Figure 6). For instance, whereas about 40 percent of secondary school teachers frequently used specific work assignments for low-performing students, this was done only rarely by about one third and not at all by one quarter of secondary school teachers.

\section{Challenges of Distance Teaching and Prerequisites for Successful Distance Teaching}

One focus of the survey was to ask teachers to evaluate different aspects of distance teaching to identify challenges that needed to be addressed to improve learning at home during school closures in the future (topic 2, Figure 7). The results were similar for elementary and secondary schools: A large percentage of teachers indicated that the distribution of work assignments worked rather well or very well and were satisfied with the support they received from colleagues and school principals. Staying in contact with students was also deemed manageable by most teachers. On the other hand, technical issues and ensuring the equal participation of all students without "losing" anyone were identified as the biggest challenges.

We complemented the closed-format items in Figure 7 with an open question asking teachers to name the most important "preconditions for successful distance learning." Categorization of the responses (see method section for details) revealed that the two most frequently mentioned requirements were referred to by elementary and secondary school teachers alike (Table 2). These requirements referred to technical equipment (mentioned by 77 percent of elementary school teachers and 75 percent of secondary school teachers), e.g., tablets or laptops for students and teachers, and IT infrastructure (60 percent and 61 percent, respectively), e.g., stable internet connections or infrastructure maintenance.

\section{Students' Attainment of Learning Objectives and Learning Progress}

Concerning the teacher-reported learning progress of students (topic 3), slightly more than half of the elementary school teachers and only about one third of the secondary school teachers stated that the majority of their students achieved the same learning progress that would have been expected in regular lessons at school (Figure 8). Similarly, about one quarter of elementary school teachers and almost 40 percent of secondary school teachers believed that their classes more or less failed in meeting the overall educational objectives during the weeks of distance teaching (Figure 7).

Based on six random forest analyses consisting of 5,000 ordinal regression trees each, we derived the relative importance of our predictor variables for explaining these two outcome variables as described in the method section. Of all predictor variables that were included in the analyses, the first seven predictors for each school type and for each dependent variable are displayed in Figure 9. We excluded all variables from further exploration and discussion that were negative, zero, or positive, but with a value that lay in the same range as the negative values as suggested by Strobl et al. (2009). These variables are bordered in red in Figure 9.

For both outcome variables, the most important predictor in elementary school is regular contact between teachers and their 

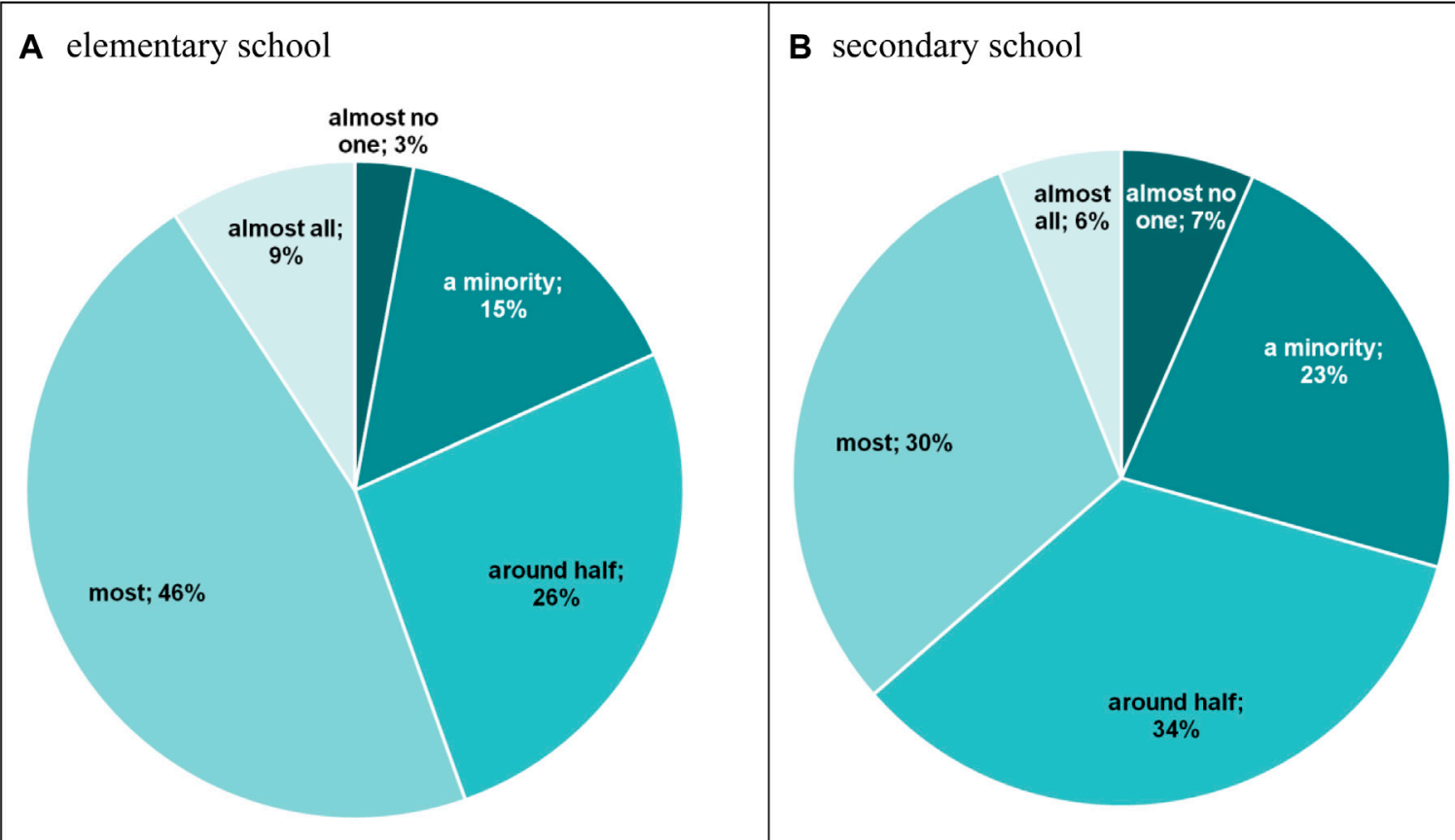

FIGURE 8 | Percentages of teachers giving the indicated responses to the question "In your opinion, what percentage of students managed to obtain at least the same learning progress during distance teaching that could have been expected during classroom teaching?" (A) elementary school. (B) secondary school.

students' parents, whereas teacher contact with students was slightly less important. In contrast, regular contact with parents was much less important in secondary school, and in secondary schools with academic track it was virtually unimportant. However, contact with the students themselves was the most important predictor variable independent of outcome variable and school track in secondary school.

The correlational structure of the remaining important variables is as follows: Especially in primary school, teachers' gender was associated with the outcome variables in the sense that women tended to report better overall learning goal achievement and better learning progress for students in comparison with regular classroom teaching. Furthermore, in subgroups where the teachers' age variable was fairly important, older teachers reported better learning progress for their students. The association of students' age or grade level, respectively, was inverse in primary versus secondary school: In primary school, teachers reported better learning progress for the younger children, whereas in secondary school, teachers reported better learning progress for students in more advanced grades. Among the factors that hindered teachers' work, lack of access to materials (i.e., due to limited access to the school building), lack of an own PC/laptop, and lack of a separate room for work at home were negatively associated with the outcome variables. However, having to care for their own children at home during distance teaching did not seem to be important.
Of the different communication channels assessed, higher frequencies of communication via ordinary mail and deposit and pick-up at school in particular were negatively associated with the outcome variables suggesting that relying on "analog" communication channels tended to fail to contribute to successful distance teaching. In contrast, the more frequent usage of digital communication channels, such as feedback and material distribution via e-mail, feedback via online platforms, or feedback via audio/video conferencing, was positively associated with the outcome variables. In primary school, the association with feedback via e-mail in particular had a relatively high variable importance. Additional factors that were relatively important as predictors for the outcome variables were the adaptation of work assignments depending on the students' individual performance and additional exercises for high performing students, fixed consultation hours for teachers, and fixed availability times for students.

\section{DISCUSSION}

The SARS-CoV-2 pandemic has had an undoubtedly tremendous impact on schools, students, and teachers, with teaching and learning processes being temporarily remotely implemented in spring 2020. In this study, our aim was to describe the impact of school closures due to the SARS-CoV-2 pandemic on elementary and secondary school education in Germany from a teacher's perspective. Moreover, we conducted an exploratory examination of the importance of different variables including teaching 


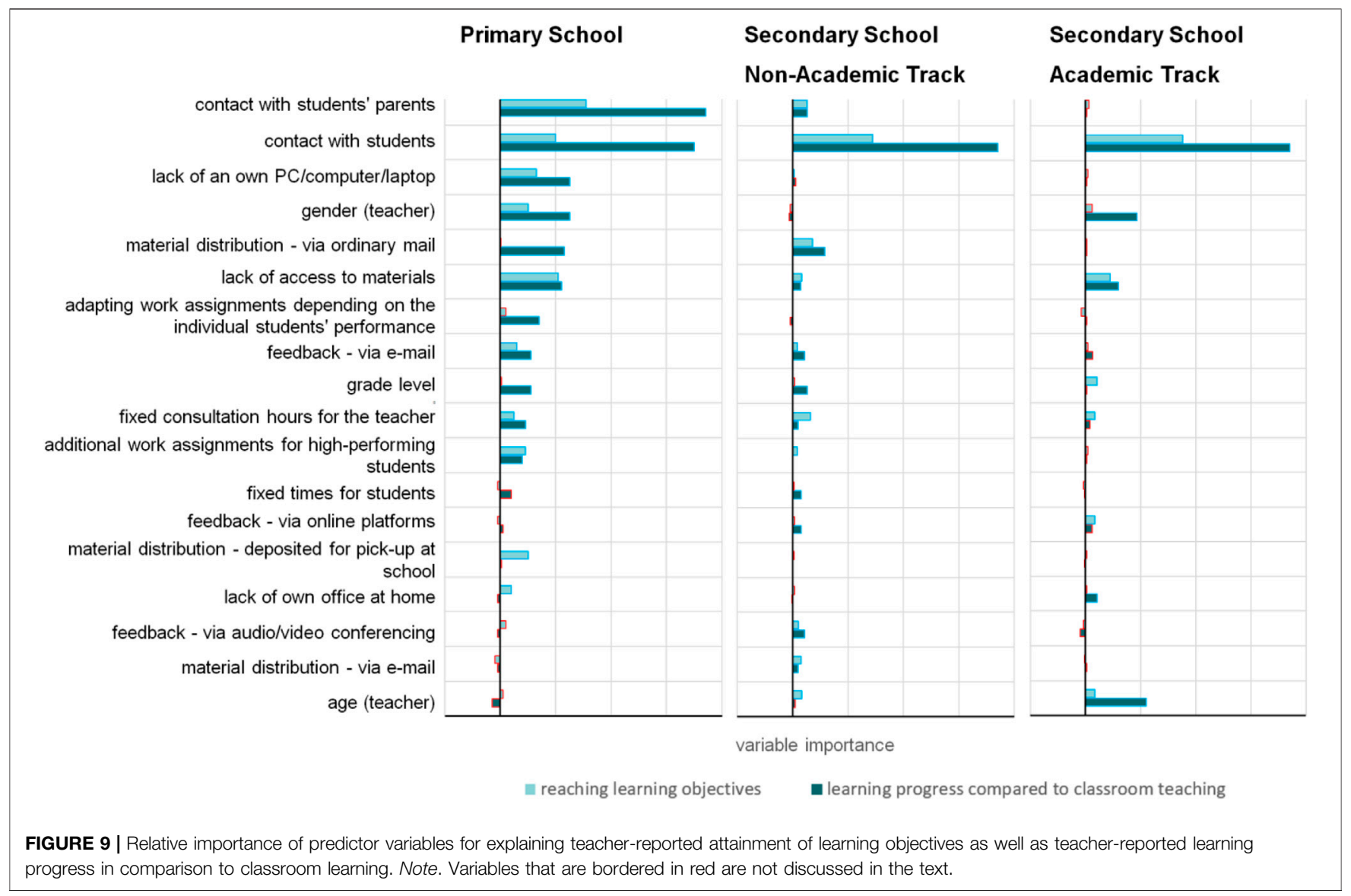

practices for teacher reports of students' attainment of learning objectives during distance teaching and their learning progress compared to regular classroom teaching. Overall, our results underline the importance of regular contact between teachers and students for the learning progress of students, the demand for faster progress regarding digitalization, and of fostering the corresponding digitalization competencies in teachers and students.

\section{The Most Important Predictor for Successful Distance Teaching: Staying in Contact With Students and Their Parents}

In our study, teachers were rather pessimistic about students' learning gains during the school closures. About one quarter of elementary school teachers and almost 40 percent of secondary school teachers believed that their classes more or less failed to meet the overall educational objectives during the weeks of distance teaching. Furthermore, only slightly more than half of the elementary school teachers and only about one third of secondary school teachers stated that the majority of their students made the same learning progress that would have been expected in regular lessons in school. These results are in line with other surveys conducted with teachers (forsa, 2020a; Schwerzmann and Frenzel, 2020; Steiner et al., 2020). Between one third and two thirds of students' parents worry about the potential negative consequences for their children's learning progress (e.g, Huber et al., 2020; Thies and Klein, 2020; Wößmann et al., 2020).

The percentages of teachers who had contact with their students' parents and their students, respectively, on a regular basis were by far the two most important determinants for teacher-reported attainment of learning objectives and learning progress for elementary school students. For secondary school students, only contact with students had a substantial impact. Fortunately, the majority of elementary and secondary school teachers reported maintaining contact with most or all of their students regularly, with a slightly higher percentage for secondary school teachers. In contrast, and as expected, the majority of elementary school teachers maintained contact with most or all of their students' parents, but for secondary school teachers, such contact was rare. Compared to the results of studies that were conducted at the beginning of the school closures in March and April 2020 (forsa, 2020a; Porsch and Porsch, 2020), the percentages reported in our survey are higher, indicating the increased involvement of students and their parents in lessons as distance teaching continued. However, around 29 percent of elementary school teachers and one fifth of secondary school teachers held contact with half or less of their students on a regular basis. There is reason to be concerned that many of these students might come from socially deprived families (e.g., since they lacked the necessary technical devices), have insufficient 
German language skills to follow the instructions, and/or are lower academic achievers, i.e., those students that would actually benefit most from regular contact and teacher support.

\section{Further Important Aspects: Digitalization and Students' Motivation}

On the basis of our results, another key area concerning distance teaching is digitalization, both in elementary and secondary schools. Although aspects relating to digitalization play a less important role for the teacher-reported attainment of learning objectives and for the learning progress of students (apart from the lack of an own computer/laptop for elementary school teachers), they seemed to be a major issue for teachers during school closures. For example, half of the elementary and secondary school teachers reported technical problems on the side of the students, 37/22 percent of elementary/secondary school teachers had problems with overcoming the technical challenges of distance teaching themselves. Correspondingly, a substantial amount of teachers saw need for improvement in technical requirements and the development/improvement of digital competencies. Comparable results and demands were found/formulated in other national and international studies (e.g., forsa, 2020a; forsa, 2020b; Murat and Bonacini, 2020; Wildemann and Hosenfeld, 2020). Altogether, this is regrettable given that technical devices and digital media have the potential to considerably ease distance teaching. For example, video conferences or chats allow for collaborative learning despite social distancing, thus resulting in cognitive as well as metacognitive activation and, subsequently, better learning outcomes (Spörer et al., 2008; Jeong et al., 2019). Furthermore, technical devices and digital media can support teachers in the timely evaluation of students' learning progress as well as in providing prompt feedback (Van der Kleij et al., 2015; McLaughlin and Yan, 2017), both of which are important for successful learning (McLaughlin and Yan, 2017; Hattie, 2020). Thus, efforts should be intensified to advance digitalization. However, access to technical devices and digital media is no panacea, but rather a precondition for participating in lessons during distance teaching (Ewing and Cooper, 2021).

Motivation to learn is considered to be an important internal learning potential (e.g., according to the utilization of learning opportunities model by Helmke and Schrader, 2013) that is also essential for self-determined work on tasks. According to the evaluation of distance teaching by teachers, special attention needs to be given to student motivation: Around 30 percent of elementary school teachers and 43 percent of secondary school teachers reported that motivating students worked (rather) badly. Correspondingly, around half of the $N=4,230$ parents of elementary and secondary school students interviewed by Wildemann and Hosenfeld (2020) reported that their children had low motivation or were not motivated at all. Working on tasks remotely requires high self-regulation skills from students, especially if teachers use analogous learning materials and presentation modes that students need to work on without the teachers' supervision. In elementary school in particular, students with low self-regulation skills need to rely on their parents' support. Again, disadvantages for students from socially deprived families, from households where German is rarely spoken, for students with special educational needs, and for low-achieving students are to be expected. Trautwein and Lüdtke (2014) suggest self-regulation training for students that can be held during school breaks or in the afternoon. If not feasible, teachers should at least use tasks or presentation modes that are within the self-regulation limits of their students. For example, video conferences or chats support collaborative learning and thus foster students' self-regulation skills.

\section{Implications and Limitations}

Educational management, policy makers, and others involved in education need to bear in mind local conditions to ensure that as many students as possible achieve their targeted learning goals and show learning gains. An overview of policy measures by various countries is provided by the UNESCO (e.g., Chang and Yano, 2020). Because countries vary in their economic and cultural characteristics, educational systems, and even experiences with distance teaching, single results of our study and corresponding implications can more easily be adopted to countries with comparable characteristics and systems. Nevertheless, the key components of our study for successful distance teaching seem to be generally valid (e.g., Daniel, 2020; Nóvoa and Alvim, 2020; Thomas and Rogers, 2020) and indicate a multitude of tasks for teachers: They need to stay in contact with students (and parents, if they teach in elementary school) to provide learning material (online and/or offline), to monitor students' learning process and progress as well as to support their students. They are supposed to adopt their lessons and learning materials, and therewith, factor in students' individual needs. Furthermore, they shall give positive feedback on a regular basis, maintain students' motivation and avoid frustration. Thus, qualifying teachers accordingly might be one key component to minimize the impact of distance teaching on students' learning progress.

Another key component, as outlined above, seems to be an increasing digitalization. According to a meta-analysis by Hillmayr et al. (2020), digital media can enhance students' learning if other instruction methods and digital media are combined and teachers are accordingly qualified. Therefore, increasing digitalization and the corresponding qualification of teachers might not only be helpful in maintaining a high quality of teaching during school closures or cohort teaching, but could also make a positive difference in future classroom teaching (Anger and Plünnecke, 2020). However, an advancing digitalization is linked to countries' economic and cultural characteristics. For example, and with regard to the latter, families in the Middle East seem to be more concerned about their children, especially daughters, using the microphone, webcams or sharing their screen during distance teaching (Khlaif et al., 2021), which may limit these students' possibilities to participate in distance teaching via technical devices and digital media. Future research should not only describe potential progress in digitalization and changes in teaching practices resulting from the pandemic, but should also focus on students' actual achievements, including 
disparities associated with disadvantaged groups of students, on students' motivation, as well as on the physical and mental health of teachers, students, and parents. A broad and international database would be desirable for examining what has been done and what worked best in order to further learn from other countries and to develop pedagogical plans to better cope with comparable situations in the future.

Concerning the limitations of our study, it needs to be noted that participation in the survey was voluntary, with the risk of under/overrepresenting certain groups of teachers and therefore not being representative of all German elementary and secondary school teachers. Furthermore, the current data is restricted to elementary school teachers from four German federal states to facilitate the comparison of results between elementary and secondary schools. However, the presented results do not differ substantially from those for the full sample of elementary school teachers from nearly all German federal states (see Schneider et al., 2020). Nevertheless, our study contributes to the ongoing debate about the impact of school closures on education by describing teaching practices during the first wave of school closures in spring 2020 and examining the impact of different variables including teaching practices on students' attainment of learning objectives and their learning progress during distance teaching.

\section{CONCLUSION}

Overall, our study contributes to the (inter)national data base concerning distance teaching during the 2020 school closures due to the SARS-CoV-2 pandemic. As most important for perceived successful distance teaching we could identify staying in touch with students in secondary school and in addition with parents in primary school. Furthermore, our results underline the demand

\section{REFERENCES}

Acee, T. W., Kim, H., Kim, H. J., Kim, J.-I., Chu, H.-N. R., Kim, M., et al. (2010). Academic Boredom in under- and Over-challenging Situations. Contemp. Educ. Psychol. 35 (1), 17-27. doi:10.1016/j.cedpsych.2009.08.002

Andrew, A., Cattan, S., Costa-Dias, M., Farquharson, C., Kraftman, L., Krutikova, S., et al. (2020). Learning during the Lockdown: Real-Time Data on Children's Experiences during home Learning. IFS Briefing Note BN288. Available at: https://www.ifs.org.uk/uploads/Edited_Final-BN288\%20Learning\%20during\% 20the\%20lockdown.pdf.

Anger, C., and Plünnecke, A. (2020). Schulische Bildung zu Zeiten der CoronaKrise [School education in times of the coronavirus crisis]. Perspektiven der Wirtschaftspolitik 21 (4), 353-360. doi:10.1515/pwp-2020-0055

Assunção Flores, M., and Gago, M. (2020). Teacher Education in Times of COVID19 Pandemic in Portugal: National, Institutional and Pedagogical Responses. J. Edu. Teach. 46 (4), 507-516. doi:10.1080/02607476.2020.1799709

Behrends, S., Engel, W., Kott, K., and Neuhäuser, J. (2018). Datenreport 2018. Ausstattung privater Haushalte mit Gebrauchsgütern. [Data report 2018. Consumer goods in private households] (bpb: Bundeszentrale für politische Bildung. Available at: https://www.bpb.de/nachschlagen/datenreport-2018/ private-haushalte-einkommen-konsum-wohnen/278199/ausstattung-privaterhaushalte-mit-gebrauchsguetern.

Boulesteix, A.-L., Janitza, S., Kruppa, J., and König, I. R. (2012). Overview of Random Forest Methodology and Practical Guidance with Emphasis on for faster progress regarding digitalization and for fostering the corresponding digitalization competencies in teachers and students. Technical devices and digital media should not only be used for the distribution of learning materials and feedback, but also for motivating students, probably even more for those living in potentially deprived learning environments.

\section{DATA AVAILABILITY STATEMENT}

Data supporting the conclusions of this article will be made available upon request to the first author.

\section{ETHICS STATEMENT}

Prior to the participation of teachers, the Ministries of Education and Cultural Affairs of the German Federal States were informed of the general aim of our research and approved the study material and procedures. Participation was voluntarily and participants gave their informed consent to take part in this online study by answering the survey questions.

\section{AUTHOR CONTRIBUTIONS}

All authors listed have made a substantial, direct, and intellectual contribution to the work and approved it for publication.

\section{ACKNOWLEDGMENTS}

We thank the IEA Hamburg for their support in contacting the schools.

Computational Biology and Bioinformatics. Wires Data Mining Knowl Discov. 2 (6), 493-507. doi:10.1002/widm.1072

Breiman, L. (2001). Random Forests. Machine Learn. 45, 5-32. doi:10.1023/a: 1010933404324

Chang, G. C., and Yano, S. (2020). How Are Countries Addressing the Covid-19 Challenges in Education? A Snapshot of Policy Measures. World Educ. Blog. doi:10.1023/A:1010933404324

Daniel, S. J. (2020). Education and the COVID-19 Pandemic. Prospects 49, 91-96. doi:10.1007/s11125-020-09464-3

Depping, D., Lücken, M., Musekamp, F., and Thonke, F. (2021). Kompetenzstände Hamburger Schüler*innen vor und während der Corona-Pandemie [Alternative pupils' competence measurement in Hamburg during the Corona pandemic]. DDS - Die Deutsche Schule, Beiheft 17, 51-79. doi:10.31244/9783830993315.03

Di Pietro, G., Biagi, F., Costa, P., Karpiński, Z., and Mazza, J. (2020). The Likely Impact of COVID-19 on Education: Reflections Based on the Existing Literature and Recent International Datasets. JRC Technical Report (Luxembourg: Publications Office of the European Union). doi:10.2760/126686

Eickelmann, B., Bos, W., Gerick, J., Goldhammer, F., Schaumburg, H., Schwippert, K., et al. (2019). ICILS 2018 \#Deutschland. Computer- und informationsbezogene Kompetenzen von Schülerinnen und Schülern im zweiten internationalen Vergleich und Kompetenzen im Bereich Computational Thinking [ICILS 2018 \#Germany. Computer and information-related competencies of students in the second international comparison and competencies in computational thinking]. New York: 
Waxmann. Available at: https://www.pedocs.de/volltexte/2019/18166/pdf/ Eickelmann_et_al_2019_ICILS_2018_Deutschland.pdf.

Engzell, P., Frey, A., and Verhagen, M. D. (2021). Learning Loss Due to School Closures during the COVID-19 Pandemic. SocArXiv Papers. doi:10.31235/ osf.io/ve4z7

Ewing, L.-A., and Cooper, H. B. (2021). Technology-enabled Remote Learning during Covid-19: Perspectives of Australian Teachers, Students and Parents. Technol. Pedagogy Edu. 30 (1), 41-57. doi:10.1080/1475939X.2020.1868562

Fickermann, D., and Edelstein, B. (2020). "Langsam vermisse ich die Schule ...": Schule während und nach der Corona-Pandemie ["I'm starting to miss school": Schooling during and after the Corona pandemic]. DDS - Die Deutsche Schule, Beiheft 16, 9-33. doi:10.31244/9783830992318.01

forsa (2020a). Das Deutsche Schulbarometer Spezial Corona-Krise [The German School Barometer - Coronavirus Crisis Special]. Available at: https://deutschesschulportal.de/unterricht/das-deutsche-schulbarometer-spezial-corona-krise/.

forsa (2020b). Das Deutsche Schulbarometer Spezial Corona-Krise: Folgebefragung [The German School Barometer - Coronavirus Crisis Special: Follow-Up Survey]. Available at: https://deutsches-schulportal.de/unterricht/lehrerumfrage-deutsches-schulbarometer-spezial-corona-krise-folgebefragung/.

Geis-Thöne, W. (2020). Häusliches Umfeld in der Krise: Ein Teil der Kinder braucht mehr Unterstützung. Ergebnisse einer Auswertung des Sozioökonomischen Panels (SOEP) [The domestic environment during the crisis: Some children need more support. Results of an analysis of the Socio-Economic Panel (SOEP)], IW-Report (15/2020). Available at: https://www.iwkoeln.de/ fileadmin/user_upload/Studien/Report/PDF/2020/IW-Report_2020_Haeusliche_ Lebenswelten_Kinder.pdf.

Gesetz zum Schutz der Teilnehmer am Fernunterricht (2020). [Law for the protection of the participants of distance learning], BGB I S. 1670, $\$ 1$ et seq. Available at: https://www.gesetze-im-internet.de/fernusg/.

Grewenig, E., Lergetporer, P., Woessmann, L., and Zierow, L. (2020). COVID-19 and Educational Inequality: How School Closures Affect Low- and High-Achieving Students. CESifo Working Paper (8648). doi:10.1016/j.jeconom.2020.03.022

Hattie, J. (2020). Hattie Ranking: Backup of 195 Effects Related to Student Achievement. Available at: https://visible-learning.org/hattie-ranking-backup195-effects/. doi:10.4324/9780367815561

Helm, C., Huber, S., and Loisinger, T. (2021). Was wissen wir über schulische LehrLern-Prozesse im Distanzunterricht während der Corona-Pandemie? - Evidenz aus Deutschland, Österreich und der Schweiz [Meta-Review on findings about teaching and learning in distance education during the Corona pandemic Evidence from Germany, Austria and Switzerland]. Zeitschrift für Erziehungswissenschaft, 1-75. doi:10.1007/s11618-021-01000-z

Helmke, A., and Schrader, F.-W. (2013). Angebots-Nutzungs-Modell der Wirkfaktoren akademischer Leistungen [Utilization of learning opportunities model], in Dorsch - Lexikon der Psychologie. Editor M. A. Wirtz (Bern, Switzerland: Huber), 147-148. Available at: https:// dorsch.hogrefe.com/stichwort/angebots-nutzungs-modell-der-wirkfaktorenakademischer-leistungen

Hillmayr, D., Ziernwald, L., Reinhold, F., Hofer, S. I., and Reiss, K. M. (2020). The Potential of Digital Tools to Enhance Mathematics and Science Learning in Secondary Schools: A Context-specific Meta-Analysis. Comput. Edu. 153, 103897. doi:10.1016/j.compedu.2020.103897

Hothorn, T., Hornik, K., and Zeileis, A. (2021). Party: A Laboratory for Recursive Partytioning. ( $R$ package version 1.3-7) [Computer software]. The Comprehensive R Archive Network. Available at: https://cran.r-project.org/ web/packages/party/vignettes/party.pdf.

Huber, S. G., Günther, P. S., Schneider, N., Helm, C., Schwander, M., Schneider, J. A., et al. (2020). COVID-19 und aktuelle Herausforderungen in Schule und Bildung [COVID-19 and the current challenges in education]. Münster, Germany: Waxmann. doi:10.31244/9783830942160

Hurrelmann, K., and Dohmen, D. (2020). Coronakrise verstärkt Bildungsungleichheit [Corona Crisis Reinforces Educational Inequality]. Das Deutsche Schulportal. Available at: https://deutsches-schulportal.de/ stimmen/das-deutsche-schulbarometer-hurrelmann-dohmen-corona-kriseverstaerkt-bildungsungleichheit/.

Janitza, S., Tutz, G., and Boulesteix, A.-L. (2016). Random Forest for Ordinal Responses: Prediction and Variable Selection. Comput. Stat. Data Anal. 96, 57-73. doi:10.1016/j.csda.2015.10.005
Jeong, H., Hmelo-Silver, C. E., and Jo, K. (2019). Ten Years of ComputerSupported Collaborative Learning: A Meta-Analysis of CSCL in STEM Education during 2005-2014. Educ. Res. Rev. 28, 100284. doi:10.1016/ j.edurev.2019.100284

Kempert, S., Edele, A., Rauch, D., Wolf, K. M., Paetsch, J., Darsow, A., et al. (2016). Die Rolle der Sprache für zuwanderungsbezogene Ungleichheiten im Bildungserfolg [The Role of Language in Immigration-Related Inequalities in Educational Attainment], in Ethnische Ungleichheiten im Bildungsverlauf. Editors C. Diehl, D. Hunkler, and C. Kristen (Springer VS), 157-241. doi:10.1007/978-3-658-04322-3_5

Khlaif, Z. N., Salha, S., Fareed, S., and Rashed, H. (2021). The Hidden Shadow of Coronavirus on Education in Developing Countries. Olj 25 (1), 269-285. doi:10.24059/olj.v25i1.2287

Klapproth, F., Federkeil, L., Heinschke, F., and Jungmann, T. (2020). Teachers Experiences of Stress and Their Coping Strategies during COVID - 19 Induced Distance Teaching. Jpr 4 (4), 444-452. doi:10.33902/JPR.2020062805

Klieme, E. (2020). Guter Unterricht - auch und besonders unter Einschränkungen der Pandemie? [Teaching quality - also and especially under the constraints of the pandemic?]. DDS - Die Deutsche Schule, Beiheft 16, 117-135. doi:10.31244/ 9783830992318.07

Landis, J. R., and Koch, G. G. (1977). The Measurement of Observer Agreement for Categorical Data. Biometrics 33 (1), 159-174. doi:10.2307/2529310

Leopoldina (2020). Dritte Ad-Hoc-Stellungnahme: Coronavirus-Pandemie - Die Krise Nachhaltig Überwinden [Third Ad Hoc Statement: Coronavirus Pandemic - Overcoming the Crisis Sustainably]. Available at: https://www. leopoldina.org/uploads/tx_leopublication/2020_04_13_Coronavirus-PandemieDie_Krise_nachhaltig_überwinden_final.pdf.

Maldonado, J. E., and De Witte, K. (2020). The Effect of School Closures on Standardised Student Test Outcomes, Discussion Paper Series, DPS20.17. Available at: https://feb.kuleuven.be/research/economics/ces/documents/DPS/ 2020/dps2017.pdf.

Mayring, P. (2015). Qualitative Content Analysis: Theoretical Background and Procedures, in Approaches to Qualitative Research in Mathematics Education. Advances in Mathematics Education. Editors A. Bikner-Ahsbahs, C. Knipping, and N. Presmeg (Springer), 365-380. doi:10.1007/978-94-017-9181-6_13

McLaughlin, T., and Yan, Z. (2017). Diverse Delivery Methods and strong Psychological Benefits: A Review of Online Formative Assessment. J. Comp. Assist. Learn. 33 (6), 562-574. doi:10.1111/jcal.12200

Murat, M., and Bonacini, L. (2020). Coronavirus Pandemic, Remote Learning and Education Inequalities, GLO Discussion Paper, 679. Available at: http://hdl. handle.net/10419/224765.

Nóvoa, A., and Alvim, Y. (2020). Nothing Is New, but Everything Has Changed: A Viewpoint on the Future School. Prospects 49, 35-41. doi:10.1007/s11125-02009487-w

Organisation for Economic Co-operation and Development (2020). Learning Remotely when Schools Close: How Well Are Students and School Prepared? Insights Form PISA. OECD. Available at: https://www.oecd.org/coronavirus/ policy-responses/learning-remotely-when-schools-close-how-well-are-studentsand-schools-prepared-insights-from-pisa-3bfdalf $7 /$.

Porsch, R., and Porsch, T. (2020). Fernunterricht Als Ausnahmesituation. Befunde einer bundesweiten Befragung von Eltern mit Kindern in der Grundschule [Home schooling as an exceptional situation. Findings from a nationwide survey of parents with primary school children]. DDS - Die Deutsche Schule, Beiheft 16, 61-78. doi:10.31244/9783830992318.03

Rjosk, C., Hoffmann, L., Richter, D., Marx, A., and Gresch, C. (2017). Qualifikation von Lehrkräften und Einschätzungen zum gemeinsamen Unterricht von Kindern mit und Kindern ohne sonderpädagogischen Förderbedarf [Teacher qualification and valuation regarding common instruction of children with and children without special educational needs], in IQBbildungstrend 2016 [IQB Trend in Student Assessment 2016. Editors P. Stanat, S. Schipolowski, C. Rjosk, S. Weirich, and N. Haag (Münster, Germany: Waxmann), pp. 335-353.

Scheerens, J. (2017). Opportunity to Learn, Curriculum Alignment and Test Preparation. A Research Review. Springer. doi:10.1007/978-3-319-43110-9

Schmid, U., Goertz, L., and Behrens, J. (2017). Monitor Digitale Bildung. Die Schulen im digitalen Zeitalter [Digital education monitor. Schools in the digital age]. Gütersloh, Germany: Bertelsmann Stiftung. Available at: https://www. 
bertelsmann-stiftung.de/fileadmin/files/BSt/Publikationen/GrauePublikationen/ BSt_MDB3_Schulen_web.pdf.

Schneider, R., Schipolowski, S., Sachse, K. A., Enke, F., and Stanat, P. (2020). Fernunterricht im Schuljahr 2019/2020: Ergebnisse der Lehrkräftebefragung des IQB [Distance teaching in the school year 2019/2020: Results of a survey among teachers by the Institute for Educational Quality Improvement]. Berlin, Germany: Institute for Educational Quality Improvement. Available at: https://www.iqb.hu-berlin.de/bt/Fernunterricht/.

Schnyder, I., Niggli, A., Cathomas, R., Trautwein, U., and Lüdtke, O. (2006). Wer lange lernt, lernt noch lange nicht viel mehr: Korrelate der Hausaufgabenzeit im Fach Französisch und Effekte auf die Leistungsentwicklung [Learning for more hours does not imply learning more: Correlating homework time and effects on performance development in French]. Psychol. Erziehung Unterricht 53, 107-121.

Schult, J., Mahler, N., Fauth, B., and Lindner, M. A. (2021). Did Students Learn Less during the COVID-19 Pandemic? Reading and Mathematics Competencies before and after the First Pandemic Wave. PsyArXiv. doi:10.31234/osf.io/pqtgf

Schwerzmann, M., and Frenzel, S. (2020). Umfrage zum Fernunterricht. Ergebnisse der Befragung im Juni 2020 [Distance learning survey. Results of the survey in June 2020]. Bildungs- und Kulturdepartement. Available at: https://www.lu. $\mathrm{ch} /$-/media/Kanton/Dokumente/BKD/Aktuelles/BKD_Fernunterricht_ Praesentation_Ergebnisse_an_MK_2020_10_14.pdf?la=de-CH.

Spörer, N., Seuring, V., Schünemann, N., and Brunstein, J. C. (2008). Förderung des Leseverständnisses von Schülern der 7. Klasse: Effekte peer-gestützten Lernens in Deutsch und Englisch [Promoting reading comprehension in 7th-grade pupils: Effects of peer-supported learning in German and English]. Z. für Pädagogische Psychol. 22 (34), 247-259. doi:10.1024/10100652.22.34.247

Statistisches Bundesamt (2020). Bildung, Forschung und Kultur: Schulen [Education, Research, and Culture: Schools]. Available at: https://www. destatis.de/DE/Themen/Gesellschaft-Umwelt/Bildung-Forschung-Kultur/Schulen/_ inhalt.html\#sprg234476.

Steiner, M., Köpping, M., Leitner, A., and Pessl, G. (2020). COVID-19 LehrerInnenbefragung - Zwischenergebnisse. Was tun, damit aus der Gesundheitskrise nicht auch eine Bildungskrise wird? [COVID-19 teaching staffsurvey - Intermediate results. What can we do to ensure that the health crisis does not become an educational crisis?]. Institut für Höhere Studien - Institute for Advanced Studies (IHS). Available at: https://www.ihs.ac.at/index.php?id=1176.

Strobl, C., Malley, J., and Tutz, G. (2009). An Introduction to Recursive Partitioning: Rationale, Application, and Characteristics of Classification and Regression Trees, Bagging, and Random Forests. Psychol. Methods 14 (4), 323-348. doi:10.1037/a0016973

Tenorth, H.-E. (2014). Kurze Geschichte der allgemeinen Schulpflicht [A brief history of compulsory education]. bpb: Bundeszentrale für politische Bildung. Available at: https://www.bpb.de/gesellschaft/bildung/zukunft-bildung/ 185878/geschichte-der-allgemeinen-schulpflicht.

Thakur, K. (2014). Differentiated Instruction in the Inclusive Classroom. Res. J. Educ. Sci. 2 (7), 10-14. Available at: http://isca.in/EDU_SCI/Archive/v2/i7/2. \%20ISCA-RJEduS-2014-025.pdf.

Thies, L., and Klein, Y. (2020). Unter Druck. Die Situation von Eltern und ihren schulpflichtigen Kin-dern während der Schulschließungen [Under pressure. The situation of parents and their school-age children during the school closures]. Düsseldorf, Germany: Vodafone Stiftung Deutschland. Available at: https://www.vodafone-stiftung.de/wp-content/uploads/2020/04/VodafoneStiftung-Deutschland_Studie_Unter_Druck.pdf.

Thom, S., Behrens, J., Schmid, U., and Goertz, L. (2017). Monitor Digitale Bildung. Digitales Lernen An Grundschulen [Digital Education Monitor. Digital Learning at Elementary Schools]. Gütersloh, Germany: Bertelsmann Stiftung. Available at: https://www.bertelsmann-stiftung.de/fileadmin/files/BSt/ Publikationen/GrauePublikationen/BST_DigiMonitor_Grundschulen.pdf.

Thomas, M. S. C., and Rogers, C. (2020). Education, the Science of Learning, and the COVID-19 Crisis. Prospects 49, 87-90. doi:10.1007/s11125-020-09468-z
Tomlinson, C. A. (2005). Grading and Differentiation: Paradox or Good Practice? Theor. Into Pract. 44 (3), 262-269. doi:10.1207/s15430421tip4403_11

Trautwein, U., Köller, O., and Baumert, J. (2001). Lieber oft als viel: Hausaufgaben und die Entwicklung von Leistung und Interesse im Mathematik-Unterricht der 7. Jahrgangsstufe [Better often Than a lot: Homework assignments and the development of performance and interest in 7 th grade mathematics class]. $Z$. für Pädagogik 47, 703-724. Available at: https://www.pedocs.de/volltexte/ 2012/4310/pdf/ZfPaed_2001_5_Trautwein_Koeller_Baumert_Lieber_oft_ Hausaufgaben_D_A.pdf.

Trautwein, U., and Lüdtke, O. (2014). Die Förderung der Selbstregulation durch Hausaufgaben - Herausforderungen und Chancen [Enhancing self-regulation through homework - Challenges and opportunities], in Kompetenz-Bildung. Editors C. Rohlfs, M. Harring, and C. Palentien (Springer), 275-288. doi:10.1007/978-3-658-03441-2_12

United Nations Sustainable Development Group (2020). Policy Brief: Education during COVID-19 and beyond. New York, NY, USA: United Nations. Available at: https://unsdg.un.org/sites/default/files/2020-08/sg_policy_brief_covid19_and_education_august_2020.pdf.

Van Ackeren, I., Endberg, M., and Locker-Grütjen, O. (2020). Chancenausgleich in der Corona-Krise: Die soziale Bildungsschere wieder schließen [Compensation of unequal educational opportunities in the Corona crisis: Closing the social education gap again]. Dds-Die Deutsche Schule 112 (2), 245-248. doi:10.31244/ dds.2020.02.10

Van der Kleij, F. M., Feskens, R. C. W., and Eggen, T. J. H. M. (2015). Effects of Feedback in a Computer-Based Learning Environment on Students' Learning Outcomes. Rev. Educ. Res. 85 (4), 475-511. doi:10.3102/0034654314564881

Van Lancker, W., and Parolin, Z. (2020). COVID-19, School Closures, and Child Poverty: A Social Crisis in the Making. The Lancet Public Health 5 (5), 243-244. doi:10.1016/S2468-2667(20)30084-0

Wildemann, A., and Hosenfeld, I. (2020). Bundesweite Elternbefragung $z u$ Homeschooling während der Covid 19-Pandemie. Erkenntnisse zur Umsetzung des Homeschoolings in Deutschland [Nationwide parent survey on homeschooling during the COVID-19 pandemic. Findings on the implementation of homeschooling in Germany]. Universität KoblenzLandau: Institut für Bildung im Kindes- und Jugendalter; Zentrum für empirische Pädagogische Forschung. Available at: http://www.zepf.eu/wpcontent/uploads/2020/06/Bericht_HOMEschooling2020.pdf.

Wößmann, L., Freundl, V., Grewenig, E., Lergetporer, P., Werner, K., and Zierow, L. (2020). Bildung in der Coronakrise: Wie haben die Schulkinder die Zeit der Schulschließungen verbracht, und welche Bildungsmaßnahmen befürworten die Deutschen? [Education during the coronavirus crisis: How have school children spent the time over the school closures and which educational measures Do Germans prefer?]. Ifo Schnelldienst 73 (09), 25-39. Available at: https://www.ifo.de/publikationen/2020/aufsatz-zeitschrift/bildung-dercoronakrise-wie-haben-die-schulkinder-die-zeit.

Conflict of Interest: The authors declare that the research was conducted in the absence of any commercial or financial relationships that could be construed as a potential conflict of interest.

Publisher's Note: All claims expressed in this article are solely those of the authors and do not necessarily represent those of their affiliated organizations, or those of the publisher, the editors and the reviewers. Any product that may be evaluated in this article, or claim that may be made by its manufacturer, is not guaranteed or endorsed by the publisher.

Copyright () 2021 Schneider, Sachse, Schipolowski and Enke. This is an open-access article distributed under the terms of the Creative Commons Attribution License (CC $B Y)$. The use, distribution or reproduction in other forums is permitted, provided the original author(s) and the copyright owner(s) are credited and that the original publication in this journal is cited, in accordance with accepted academic practice. No use, distribution or reproduction is permitted which does not comply with these terms. 